\section{Jurnal Kimia Sains dan Aplikasi Journal of Scientific and Applied Chemistry}

Journal homepage: http://ejournal.undip.ac.id/index.php/ksa

\title{
Antibacterial Activity and Chemical Composition of Red Peacock Flower (Caesalpinia pulcherrima L.) Leaf Essential Oil
}

\author{
Novena Risnalani Rintank Constani ${ }^{a}$, Hartati Soetjipto ${ }^{a,{ }^{*}}$, Sri Hartini ${ }^{a}$ \\ ${ }^{a}$ Chemistry Department, Faculty of Science and Mathematics, Satya Wacana Christian University, Salatiga, Central Java, Indonesia \\ * Corresponding author: hartati.sucipto@uksw.edu
}

https://doi.org/10.14710/jksa.22.6.269-274

\author{
Article Info \\ Article history: \\ Received: $9^{\text {th }}$ August 2019 \\ Revised: $1^{\text {st }}$ October 2019 \\ Accepted: $4^{\text {th }}$ October 2019 \\ Online: $30^{\text {th }}$ November 2019 \\ Keywords: \\ Caesalpinia pulcherrima; \\ antibacterial activity; \\ essential oil; peacock \\ flower; barbados pride
}

\begin{abstract}
Peacock flower (Caesalpinia pulcherrima L.) leaves contain essential oils which can be used as an ingredient in cosmetics, perfume, aromatherapy, medicine, and supplements. The study was conducted to obtain essential oils from peacock flower leaves and determine the antibacterial activity against gram-positive bacteria (Bacillus subtilis and Staphylococcus aureus) and gram-negative (Escherichia coli and Pseudomonas aeruginosa). Antibacterial activity test was carried out by the agar diffusion method, using paper discs. Measurements were made for the inhibition zone diameter (IZD) that appeared, while the essential oil component was analyzed using GC-MS. The results showed that the peacock flower leaves (C. pulcherrima) had a moderate to strong antibacterial effect at a concentration of $7.5 \%-20 \%$ against grampositive bacteria (B. subtilis and $S$. aureus) and gram-negative bacteria (E. coli and $P$. aeruginosa). Gram-negative $E$. coli bacteria are relatively more sensitive to peacock flower leaf essential oil compared to other test bacteria. Peacockflower (C. pulcherrima) leaf essential oil is composed of 7 main components namely $\beta$-Cubebene $33.87 \%$; Caryophyllene 23.00\%; $\gamma$-Elemene 13.18\%; $\alpha$-Pinene 10.96\%; Cadina-1(10),4-diene 10.20\%; Copaene; $7.09 \%$; $\beta$-Pinene $1.70 \%$.
\end{abstract}

\section{Introduction}

Peacock flower (Caesalpinia pulcherrima L.) is one of the ornamental plants of the Fabaceae family that grows in Indonesia. Guno et al. (2009) reported that peacock flower leaves contain essential oils, flavonoids, glycosides, and sterols. Essential oils can be used as ingredients in the fields of cosmetics, perfume, aromatherapy, medicine, and supplements [1].

Usman et al. [2] reported on the acquisition of red and yellow varieties of peacockflowers (C. pulcherrima) leaves in Nigeria using the distillation method. The essential oil compositions of the peacock flower (C. pulcherrima) leaves of the red and yellow varieties obtained were $0.50 \%$ and $0.52 \% \mathrm{v} / \mathrm{w}$ [2]. In the study of Vivek et al. [3], it is reported that the methanol extracts of leaves and flowers of the peacock flower (C. pulcherrima) plant show antimicrobial activity against pathogenic bacteria. The results show that the flower extract inhibited more bacterial growth than leaf extract from the peacock flower plant. At a dose of $100 \mu \mathrm{L}$ leaf or flower extract (20 $\mathrm{mg} / \mathrm{mL}$ ), each yielded IZD of $1.9 \mathrm{~cm}$ and $1.4 \mathrm{~cm}$, respectively [3]. Antibacterial test with diffusion method was carried out on pathogenic bacteria composing of Staphylococcus aureus, Salmonella typhi, Candida albicans, and Cryptococcus neoformans. Peacock flower plant contains secondary metabolites such as diterpenoids, phenolics, flavonoids, triterpenoids, and lactones that cause peacock flowers to have biological activity [4].

Njoku Isaac et al. [5] reported that the attainment of peacock flower (C. pulcherrima) leaf essential oil of the red flower variety in Nigeria using the distillation method with differing drying condition, namely fresh, air-dried, sun-dried, and oven-dried leaves, each yielded $0,63 \%$, $0.90 \%, 0.20 \%$, and $0.58 \%$. The analysis of chemical composition contained in the essential oil of peacock 
flower leaves using GC-MS detected the presence of 26 chemical compounds in the fresh leaf essential oil [5].

Leaf and stem bark extracts from the Peacock Flower (C. pulcherrima) plant displayed antibacterial activity. With the agar diffusion method, antibacterial activity tests were carried out on six bacteria, i.e., Staphylococcus aureus, Bacillussubtilis, Escherichia coli, Pseudomonas aeruginosa, Salmonella typhi and Klebsiella pneumoniae, which were then observed by calculating the inhibition zone diameter. Peacock flower (C. pulcherrima) bark extract showed higher antibacterial activity compared to the leaf extract, especially against $S$. typhi bacteria. At a concentration of $100 \mathrm{mg} / \mathrm{mL}$, the bark extract of peacock flower (C. pulcherrima) produced IZD of $15 \mathrm{~mm}$, while the leaf extract produced IZD of $12 \mathrm{~mm}$. The extracts have inhibitory activity against organisms due to the presence of bioactive compounds such as alkaloids, flavonoids, and tannins [6].

In general, essential oils have an antibacterial effect, and, therefore, red peacock flower leaves were selected as a source of essential oil. The red variety of the plant was chosen because it is more often found than the yellow variety. Additionally, the constituent components of the red flower plant kind are more abundant ( 55 components with nine significant components each having levels of more than $4 \%$ ) than the yellow flower plant (53 components with three significant components, each having levels of more than 4\%) [2].

Research reports on peacock flowers in Indonesia generally use crude extracts from methanol solvent. However, there are no data for essential oils. Meanwhile, research reports on the existing peacock leaf essential oil originate from Africa, meaning that the novelty of this study is the use of peacock leaf essential oil from Indonesia as an antibacterial agent. The primary purpose of this study is to obtain red peacock flower leaf essential oil, determine its antibacterial activity against grampositive bacteria (Bacillus subtilis and Staphylococcus aureus) and gram-negative bacteria (Escherichia coli and Pseudomonas aeruginosa), as well as identifying the chemical composition of essential oil of red peacock flower plant using GC-MS.

\section{Methodology}

\subsection{Materials and Equipment}

The materials used in this study include the leaves of the red peacock flower (C. pulcherrima) plant obtained from the Salatiga and its surrounding areas (Central Java, Indonesia). This plant has been determined by Mr. Soenarto Notosudarmo M.Sc (Jelami taxonomist), and the voucher is stored at the FSM Natural Product Chemistry Laboratory. The research was also carried out at the Satya Wacana Christian University's FSM Natural Product Chemistry Laboratory in October-December 2018. The chemicals used were pro-analysis standards from EMerck or Smart Lab.

\subsection{Sample Preparation}

The leaves of peacock flower (C. pulcherrima) leaves with red-colored flowers was cleaned and separated from the stalks.

\subsubsection{Essential Oil Extraction}

A total of $1 \mathrm{~kg}$ of fresh peacock flower leaves was distilled (steam distillation) for 8 hours (until no essential oil was released). The water and essential oil were separated using a Clevenger apparatus. $\mathrm{Na}_{2} \mathrm{SO}_{4}$ anhydrous was added so that the essential oil was wholly separated from the water. The essential oil obtained was stored in a sample bottle and placed in a refrigerator until a series of analysis was carried out.

\subsubsection{Antibacterial Activity Test with Agar Diffusion Method (Kirby - Bauer in American Society for Microbiology, 2016) [7]}

Testing of the antibacterial activity of the essential oil of peacock flower (C. pulcherrima) against Bacillus subtilis, Staphylococcus aureus, Escherichia coli, and Pseudomonas aeruginosa, was carried out by diffusion method using Schleicher and Schuell 2668 Ref. No. 10321260, D60222274-1 with a diameter of $6 \mathrm{~mm}$ and Tween 80 as an emulsifier. A paper disc that had been dripped with essential oils with variation in the concentrations of $7.5 \%, 10 \%, 12.5 \%, 15 \%$, and $20 \%(\mathrm{w} / \mathrm{v})$, as much as $20 \mu \mathrm{L}$, with the same relative distance from one to another, was put onto the solidified agar medium. The disk was then incubated at $37^{\circ} \mathrm{C}$ for 24 hours. As a negative control, Tween 80 was used whereas for the positive control, tetracycline $30 \mu \mathrm{g}$ was used. The measurements were done by looking at the Inhibition Zone Diameter (IZD) of the resulting inhibition areas.

\subsection{Essential Oil Chemical Components Analysis using GC-MS}

Analysis of the chemical composition of peacock flower (C. pulcherrima) essential oil was done using Gas Chromatography-Mass Spectrometry (GC-MS) of the Perkin Elmer Clarus 680 brand. Operating conditions used include the use of the Perkin Elmer Elite 5 MS column with a length of 30 meters, diameter $250 \mu \mathrm{m}$, and a temperature of $70^{\circ} \mathrm{C}$. The sample was injected as much as $1 \mu \mathrm{L}$ with an oven temperature of $70^{\circ} \mathrm{C}$ increased to 200 ${ }^{\circ} \mathrm{C}$ in 2 minutes. The split injector was at $250^{\circ} \mathrm{C}$ in temperature with a pressure of $13.7 \mathrm{kPa}$, and a split ratio of 70: 1 . Whereas the helium carrier gas was streamed at 1 $\mathrm{mL} / \mathrm{min}$ with $\mathrm{EI}^{+}$ionization.

\subsection{Data Analysis}

The resulting research data were analyzed statistically using the Variance Analysis method for sample observation (Randomized Design of Sub Sampling Group) with 5 treatments in the form of a dose of essential oil which are $7.5 \%, 10 \%, 12.5 \%, 15 \%$, and $20 \%(\mathrm{w} / \mathrm{v}), 5$ replications, and 4 subsampling (2 Gram-Positive bacteria and 2 Gram-Negative bacteria). Inter-average 
testing used the Honest Significant Difference (HSD) test with a significance level of $5 \%$.

\section{Results and Discussion}

\subsection{Yield and physical properties of red peacock flower} (C. pulcherrima) leaf essential oil

The average yield and physical properties of the red peacock (C. pulcherrima) essential oil obtained through the steam distillation method for 8 hours are presented in Table 1. When compared with other two similar studies, the yield of the red peacock flower (C. pulcherrima) fresh leaf essential oil obtained in this study was $0.32 \%$, relatively lower than that of [2] at $0.50 \%$ and Njoku Isaac et al. [5] at $0.63 \%$. The difference in the yields of essential oils from the same species is possible because of the differing conditions of the place of growth and climates, which are very influential on the essential oil products [8].

Table 1. The yields and physicochemical properties of the distillation of peacock flower leaf essential oil

\begin{tabular}{|c|c|c|c|c|}
\hline \multirow[t]{2}{*}{ Parameter } & \multicolumn{4}{|c|}{$\begin{array}{c}\text { The results of peacock flower (C. pulcherrima) leaves } \\
\text { essential oil }\end{array}$} \\
\hline & Current study & $\begin{array}{l}\text { Usman et al. } \\
\text { [2] }\end{array}$ & $\begin{array}{l}\text { Njoku Isaac et } \\
\text { al. [5] }\end{array}$ & Description \\
\hline Yield & $0.32 \%$ & $0.50 \%$ & $0.63 \%$ & $\begin{array}{l}\text { Fresh } \\
\text { leaves }\end{array}$ \\
\hline Color & Yellow & - & - & - \\
\hline Aroma & $\begin{array}{c}\text { Unique } \\
\text { peacock } \\
\text { flower aroma }\end{array}$ & - & - & - \\
\hline Density & $0,9320 \mathrm{~g} / \mathrm{mL}$ & - & - & - \\
\hline $\begin{array}{l}\text { Essential oil } \\
\text { components }\end{array}$ & 12 & 57 & 26 & $\begin{array}{l}\text { Fresh } \\
\text { leaves }\end{array}$ \\
\hline $\begin{array}{l}\text { Most abundant } \\
\text { component }\end{array}$ & $\begin{array}{c}\beta \text {-Cubebene } \\
33.87 \%\end{array}$ & $\begin{array}{c}{ }^{\gamma-} \\
\text { Terpinene } \\
44,4 \%\end{array}$ & $\begin{array}{c}\text { Caryophyllene } \\
15.5 \%\end{array}$ & $\begin{array}{l}\text { Fresh } \\
\text { leaves }\end{array}$ \\
\hline
\end{tabular}

The density of peacock flower (C. pulcherrima) essential oil obtained is $0.9320 \mathrm{~g} / \mathrm{mL}$. This result is supported by the finding of Nugraheni et al. [9], which states that the density of essential oils at $25^{\circ} \mathrm{C}$ is between $0.696-1.188 \mathrm{~g} / \mathrm{mL}$. The product of the distillation of peacock flower (C. pulcherrima) leaf essential oil can be seen in Figure 1.

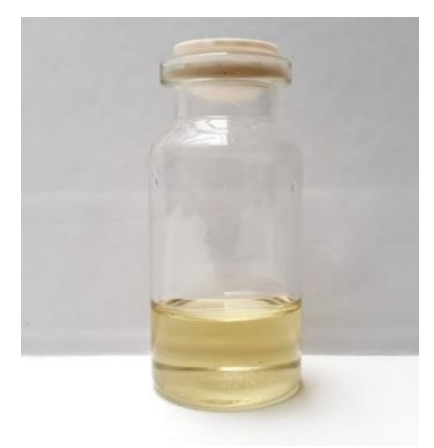

Figure 1. Peacock flower (C. pulcherrima) leaf essential oil

\subsection{Antibacterial Activity Test Results of Peacock Flower (C. pulcherrima) Essential Oil on Gram- Positive and Gram-Negative Bacteria}

Measurements of the inhibition zone diameter that appeared as a mean of testing of antibacterial effect are presented in Table 2.

Table 2. The average diameter of the inhibition zone $(\dot{x} \pm$ $\mathrm{S} \mathrm{mm}$ ) of the essential oil of peacock flower (C. pulcherrima) leaves on gram-positive and gram-negative bacteria

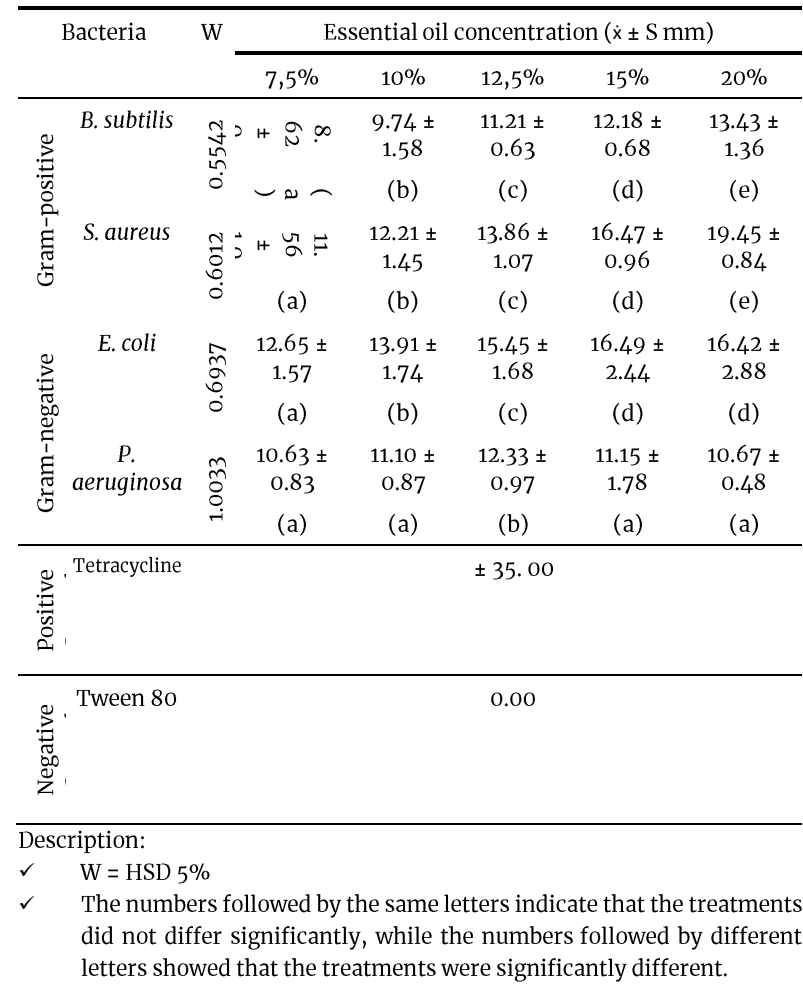

Table 2 shows that the essential oil of peacock flower (C. pulcherrima) leaves has positive antibacterial results against both gram-positive and gram-negative bacteria. The antibacterial reacts with the test bacteria by damaging the cell wall, damaging the plasma membrane, inhibiting protein synthesis, inhibiting the synthesis of nucleic acids, or inhibiting the synthesis of important metabolites in bacteria [10].

Elgayyar et al. [11] reported that the antibacterial effect of the material is shown by IZD, which is grouped into three categories: strong (IZD> $11 \mathrm{~mm}$ ), moderate (IZD between $6-11 \mathrm{~mm}$ ) and low (IZD $<6 \mathrm{~mm}$ ) [11]. The results indicate that the essential oil of peacock flower $(C$. pulcherrima) leaves have a moderate to strong antibacterial effect at a concentration of $7.5 \%-20 \%$.

Gram-negative bacteria ( $E$. coli) turned out to be relatively more sensitive to the essential oil produced compared to $P$. aeruginosa and gram-positive bacteria ( $B$. subtilis and $S$. aureus). Table 2 shows that the antibacterial effect on $E$. coli bacteria has higher IZD than that of other test bacteria. According to Pelezar and Chan (2008), gram-negative bacteria have a thick cell wall structure (outer membrane and lipopolysaccharide), high lipid 
levels, and single peptidoglycan. The peptidoglycan layer of gram-negative bacteria is thinner compared to grampositive bacteria, which implies that if the cell wall is damaged, it is easier to penetrate compounds from the outside [12]. Essential oils that penetrate the membrane can damage the cytoplasm and protein [13]. In addition, bacterial phospholipids are also soluble in essential oils due to the presence of phenol or alcohol groups [14].

In this study, tetracycline was used as a standard antibiotic or positive control since tetracycline is an antibiotic that can inhibit the growth of almost all types of bacteria, both gram-negative and gram-positive. Tetracycline works to inhibit protein synthesis by blocking the addition of amino acids of the peptide chain in bacterial growth [15]. The antibacterial ability of the peacock flower (C. pulcherrima) leaf essential oil is lower than the positive control (Tetracycline), shown in the diameter of the tetracycline inhibition with an (IZD) value of $\pm 35.00 \mathrm{~mm}$. Meanwhile, an emulsifier (Tween 80 ) with a $10 \%$ concentration was used as a negative control. The result obtained did not show any antibacterial effect on gram-positive or gram-negative bacteria shown by the diameter of the inhibition area (IZD) of the $10 \%$ Tween 80 at $0.00 \mathrm{~mm}$. The essential oil solution with concentrations of $7.5 \% ; 10 \% ; 12.5 \% ; 15 \%$; and $20 \%$, each contains Tween 80 with concentrations of $3 \% ; 4 \% ; 5 \%$; $6 \%$; and $8 \%$. Concentrations of Tween 80 contained in the essential oil are lower than $10 \%$; thus, it would not affect the IZD produced in the antibacterial testing of peacock flower leaf essential oil. The use of Tween 80 is very effective as an emulsifier for essential oils because it has the ability to increase solubility in water [16].

\subsection{Analysis of Composition of Peacock Flower (C. pulcherrima) Essential Oil}

The results of the GC-MS analysis show that there are seven main components making up the essential oil, each of which appears as a peak on the chromatogram (Figure 2).

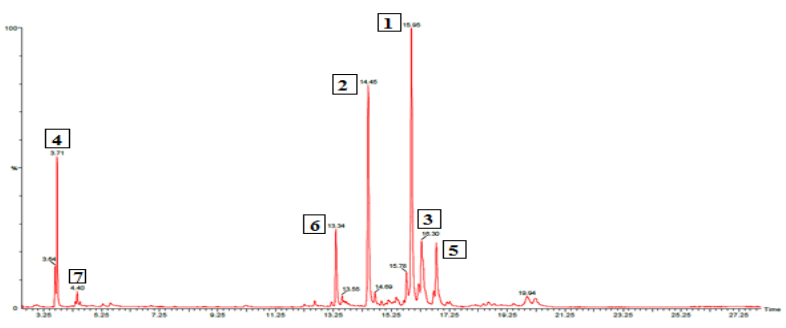

Figure 2. Chromatogram of Peacock Flower (C. pulcherrima) Essential Oil

Chromatogram of peacock flower (C. pulcherrima) leaf extract shows seven peaks of dominant components: peaks 1, 2, 3, 4, 5, 6 and 7 (Figure 2) with successive retention times of $15.95 ; 14,45 ; 16.30 ; 3.71 ; 16.81 ; 13,34$; and 4.40. Identification analysis was done by comparing each peak that appears with the Wiley database. Peak number 1, with a retention time of 15.95, has fragmentation similar to the $\beta$-Cubebene compound
(Wiley's database). Thus, the peak is believed to be a $\beta$ Cubebene compound. $\beta$-Cubebene appears at the first peak with a level of $33.87 \%$, it has a molecular formula of $\mathrm{C}_{15} \mathrm{H}_{24}$ with a molecular weight of $204,357 \mathrm{~g} / \mathrm{mol}$, and it is a class of organic compounds known as sesquiterpenoids or terpene [17].

The identification of peak number 2 with the Wiley database was conducted in the same way. Peak number 2 with a retention time of 14.45 has fragmentation similar to Caryophyllene compounds (Wiley's database). Peak number 2 is, therefore, designated as a Caryophyllene compound with a level of $23.00 \%$. Caryophyllene is the most common sesquiterpenoid compound contained in many essential oils that have a role as non-steroidal antiinflammatory drugs, metabolites from plants and fungi, medicinal/pharmaceutical ingredients, or source health benefits [18]. Caryophyllene has the molecular formula $\mathrm{C}_{15} \mathrm{H}_{24}$ with a molecular weight of $204.357 \mathrm{~g} / \mathrm{mol}$. In the same way, the identification of the rest of the seven peaks detected implies that all peaks have fragmentation similar to the Wiley database shown in Table 3.

Table 3. Main Chemical Components of Peacock Flower (Caesalpinia pulcherrima L.) Essential Oil

\begin{tabular}{cccc}
\hline $\begin{array}{c}\text { No } \\
\text { Peak }\end{array}$ & $\begin{array}{c}\text { Retention } \\
\text { Time }\end{array}$ & $\begin{array}{c}\text { Chemical } \\
\text { Component }\end{array}$ & $\begin{array}{c}\text { Content } \\
(\%)\end{array}$ \\
\hline 1 & 15.949 & $\beta$-Cubebene & $33.87 \%$ \\
2 & 14.453 & Caryophyllene & $23.00 \%$ \\
3 & 16.299 & $\begin{array}{r}\text {-Elemene } \\
\text { C-Pinene }\end{array}$ & $13.18 \%$ \\
4 & 3.714 & $10.96 \%$ \\
5 & 16.809 & Cadina-1(10), 4- & $10.20 \%$ \\
& & diene & \\
6 & 13.338 & Copaene & $7.09 \%$ \\
7 & 4.404 & $\beta$-Pinene & $1.70 \%$ \\
\hline
\end{tabular}

Usman et al. [2] reported that peacock leaf essential oil is composed of 57 components, including $28.6 \%$ sesquiterpenoid. Its most dominant compounds are $\gamma^{-}$ Terpinene 44.4\%; Germacrene B 14.3\%; $\beta$-Pinene7.4\% Alloocimene 5.9\%; Myrcene 5.6\%; Farnescene 5.3\%; $\beta$ Caryophyllene $5.1 \%$, and $\alpha$-Pinene $4.2 \%$ [2]. Whereas Njoku Isaac et al. [5] reported that the peacock leaf essential oil is composed of 26 components with 54.20$70.0 \%$ are sesquiterpenoids and its most dominant compounds are Caryophyllene 15.51\%; $\alpha$-Cadinol 14.36\%; $\checkmark$-Muurolene $13.28 \%$; Nerolidol 8.32\%; Candiene $4.78 \%$; $\checkmark$-unsure $4.70 \%$; Copaene $2.31 \%$ and $\beta$-Cubebene $0.32 \%$ [5]. When compared with the two studies mentioned, there are differences found, both in the composition and level of content of the essential oil components of peacock flower (C. pulcherrima) essential oil, such as the Caryophyllene compounds. Caryophyllene is a sesquiterpenoid compound that is found in all essential oils of peacock flower leaves studied despite having different levels. The percentage content of the compound Caryophyllene in this study is $23.00 \%$; in the study of Usman et al. [2] is $5.1 \%$, while Njoku Isaac et al. [5] is 
$15.51 \%$. For the $\beta$-Cubebene compound which is one of the main components found in this study was only found in a relatively small amount in the research of Njoku Isaac et al. [5] (0.32) and did not make an appearance in the study of Usman et al. [2]. The $\alpha$-Pinene compound at $10.96 \%$ was also found in the study of Usman et al. [2] (4.2\%); however, it did not appear in the study of $[2,5,8]$. Differences in the composition and level of compounds in the essential oil of peacock flower (C. pulcherrima) leaves are possible due to the differences in environmental factors where plants grow, such as soil and climate conditions that determine the quality of essential oils produced [8].

The components in the essential oil with a relatively high level of content such as $\beta$-Cubebene $33.87 \%$, Caryophyllene $23.00 \%$, and so forth are influential on the bioactivity of the essential oil as anti-bacteria. In essential oils, the bioactivity effect that appears can be caused by the synergistic effects of several components. This research can be used as primary data to enrich the scientific knowledge of plant essential oils in Indonesia. In general, the antibacterial bioactivity possessed by essential oils has the potential to be developed into natural antibiotics. This study also opens knowledge of the opportunities present to increase the benefits of peacock flower plants not only as ornamental plants but also as sources of essential oils and medicinal plants.

\section{Conclusion}

The peacock flower (C.pulcherrima. L) essential oil yielded was $0.32 \%$. This essential oil has a strong antibacterial effect against gram-negative bacteria, especially against $E$. coli and $P$. aeruginosa, at a concentration of $7.5 \%$. This is also true for the grampositive bacteria, especially $S$. aureus, at a concentration of $7.5 \%$ and B. subtilis at a concentration of $12.5 \%$. The seven main constituent components of peacock flower ( $C$. pulcherrima. L) essential oil are $\beta$-Cubebene $33.87 \%$; Caryophyllene $23.00 \%$; $\gamma$-Elemene $13.18 \%$; $\alpha$-Pinene 10.96\%; Cadina-1 (10), 4-diene 10.20\%; Copaene $7.09 \%$; and $\beta$-Pinene $1.70 \%$.

\section{Acknowledgment}

This work was supported by the Ministry of Higher Education and Scientific Research of Indonesia.

\section{References}

[1] G. S. Chakraborthy, R. S. Badujar and C. R. Pardeshi, Analgesic activity of chloroform extract of Caesalpinia pulcherrima, Journal of Pharmacy Research, 2, 7, (2009) 1199-1200

[2] LA Usman, MF Zubair, NO Olawore, M Ashamu, RO Ismaeel and IA Oladosu, Chemical constituents of leaf essential oils of two varieties of Caesalpinia pulcherrima Linn growing in north central Nigeria, Elixir Organic Chemistry, 5, 2, (2012) 114-116

[3] MN Vivek, M Manasa, S Pallavi, Yashoda Kambar, MM Asha, M Chaithra, $\mathrm{N}$ Mallikarjun and $\mathrm{R}$
Onkarappa, Antimicrobial and Antioxidant activity of leaf and flower extract of Caesalpinia pulcherrima, Delonix regia and Peltaphorum ferrugineum, Journal of Applied Pharmaceutical Science, 3, 8, (2013) 64-71 https://doi.org/10.7324/JAPS.2013.3811

[4] Jing-Yu Zhang, Wu Fei-Hua, Qu Wei and Jing-Yu Liang, Two new cassane diterpenoids from the seeds of Caesalpinia sappan Linn, Chinese journal of natural medicines, 10, 3, (2012) 218-221

[5] S Njoku Isaac, T Asekun Olayinka and I Familoni Oluwole, The Effect of Drying Methods on the Chemical Composition of the Essential Oil of Caesalpinia Pulcherrima Growing in Lagos, Nigeria, Covenant Journal of Physical \& Life Sciences, 4, 2, (2016) 28-34

[6] OludareTemitope Osuntokun, J. U. Julianah and O. A. Thonda, Bioprospective Screening of Antibacterial and Phytochemical Activity of Caesalpinia Pulcherrima (Pride of Barbados) on Selected Clinical Isolate, Bioequivalence \& Bioavailability International Journal, 1, 3, (2017) 1-11

[7] Jan Hudzicki, Kirby-Bauer disk diffusion susceptibility test protocol, in, American Society for Microbiology, 2009, pp. 1-23.

[8] Sara Burt, Essential oils: their antibacterial properties and potential applications in foods-a review, International Journal of Food Microbiology, 94, 3, (2004) 223-253 https://doi.org/10.1016/j.ijfoodmicro.2004.03.022

[9] Krisnawati Setyaningrum Nugraheni, Lia Umi Khasanah, Rohula Utami and Baskara Katri Anandhito, Pengaruh Perlakuan Pendahuluan dan Variasi Metode Destilasi terhadap Karakteristik Mutu Minyak Atsiri Daun Kayu Manis (C. burmanii), Jurnal Teknologi Hasil Pertanian, 9, 2, (2016) 51-64

[10] Sylvia T. Pratiwi, Mikrobiologi Farmasi, Erlangga, Jakarta, 2009.

[11] M. Elgayyar, F. A. Draughon, D. A. Golden and J. R. Mount, Antimicrobial Activity of Essential Oils from Plants against Selected Pathogenic and Saprophytic Microorganisms, Journal of Food Protection, 64, 7, (2001) 1019-1024 https://doi.org/10.4315/0362-028X-64.7.1019

[12] Michael J. Pelczar, E.C.S. Chan and Noel R. Krieg, Microbiology, McGraw-Hill Education, 1998.

[13] H. J. D. Dorman and S. G. Deans, Antimicrobial agents from plants: antibacterial activity of plant volatile oils, Journal of Applied Microbiology, 88, 2, (2000) 308-316 https://doi.org/10.1046/j.1365-2672.2000.00969.x

[14] Gustafson, Liew, Chew, Markham, Bell, Wyllie and Warmington, Effects of tea tree oil on Escherichia coli, Letters in Applied Microbiology, 26, 3, (1998) 194198 https://doi.org/10.1046/j.1472-765X.1998.00317.x

[15] B.G. Katzung, S.B. Masters and A.J. Trevor, Basic and Clinical Pharmacology, 12th edition ed., McGraw-Hill Education, 2012.

[16] Rina Wahyuni, Auzal Halim and Rina Trifarmila, Uji Pengaruh Surfaktan Tween 80 Dan Span 80 Terhadap 
Solubilisasi Dekstrometorfan Hidrobromida, Jurnal Farmasi Higea, 6, 1, (2017) 1-10

[17] Zuobing Xiao, Jiaying Chen, Yunwei Niu and Feng Chen, Characterization of the key odorants of fennel essential oils of different regions using GC-MS and GC-O combined with partial least squares regression, Journal of Chromatography B, 1063, (2017) 226-234

https://doi.org/10.1016/j.jchromb.2017.07.053

[18] Rini Pujiarti, Titis Budi Widowati, Kasmudjo Kasmudjo and Sigit Sunarta, Kualitas, Komposisi Kimia, dan Aktivitas Anti Oksidan Minyak Kenanga (Cananga odorata), Jurnal Ilmu Kehutanan, 9, 1, (2015) 3-11 